\title{
The importance of legislative measures on tobacco control in Brazil
}

\author{
Antonio Pedro Mirra ${ }^{1 *}$, Adriana Pereira de Carvalho ${ }^{2}$ \\ ${ }^{1}$ Coordinator of the Committee on Tobacco Control of the Brazilian Medical Association (AMB), Member of the Commission for Prevention and Control of Smoking, Faculty of Public Health, Universidade de São Paulo; \\ Emeritus Member of the Brazilian College of Surgeons and the Brazilian Society of Cancerology (SBC), São Paulo, SP, Brazil \\ ${ }^{2}$ Attorney at law. Legal Coordinator of the Tobacco Control Alliance, São Paulo, SP, Brazil
}

Study conducted by Associação Médica Brasileira (AMB) and Aliança de Controle do Tabagismo (ACT), São Paulo, SP, Brazil

Article received: $2 / 6 / 2017$ Accepted for publication: 4/3/2017

*Correspondence: Address: Av. Doutor Arnaldo, 715 São Paulo, SP - Brazil Postal code: 01246-904 apmirra@usp.br

http://dx.doi.org/10.1590/1806-9282.63.10.917

\section{SUMMARY}

Introduction: In the tobacco control program, educational, socioeconomic, ecological and legislative actions should be planned. Legislative actions should include the federal, state and municipal spheres, have a primarily preventive purpose and federal reach.

Objective: Survey of bills presented in both legislative houses at federal level, House of Representatives and Senate (which together form the National Congress) and the resulting laws.

Method: In the period from 1965 to 2015, 254 bills were filed with the House of Representatives and, from 1971 to 2015, 68 others were presented to the Senate.

Results: In the House of Representatives, of the 254 bills, $68.9 \%$ were archived/rejected/returned, $14.9 \%$ did not have a result, $12.2 \%$ are currently being processed/analyzed by commissions, $2.0 \%$ refer to the inclusion of amendments/law annexes, $1.2 \%$ were transformed into legal norm/ proposition of origin and $0.8 \%$ were transformed into laws. In the Senate, of the 68 bills, $19.1 \%$ were filed, $33.8 \%$ did not have a result, $4.4 \%$ were currently being processed, and $42.7 \%$ referred to changes in the law. Anti-tobacco actions were more prevalent in the periods 1979-1984 by the AMB, $1985-2007$ by MS/INCA, and in $2008-2015$ by the ACT.

Conclusion: Tobacco control legislation has progressed constantly, with the provocation of legislators from both Houses triggered by the MS/INCA and civil entities committed to smoking control, such as a number of nongovernmental organizations (especially the AMB and the ACT).

Keywords: tobacco use disorder/prevention \& control, smoking/legislation $\&$ jurisprudence, legislation.

\section{INTRODUCTION}

Smoking should be considered a public health problem, as it presents the characteristics of a pandemic.

A public policy of tobacco control should be broad, with participation of all segments of civil society.

In the tobacco control program, educational, socioeconomic, ecological and legislative actions should be planned. Partnerships at the federal, state and municipal levels, as well as participation of civil society committed to tobacco control, including non-governmental organizations, are required. ${ }^{1}$

Educational actions should reach the general population, being implemented in elementary, middle and tech- nical schools among children and adolescents, education and health professionals, also being part of the curriculum of medical science schools.

Socioeconomic actions must aim to increase the tax and prices on cigarettes in order to hamper access to the product, cease to finance and subsidize the price of tobacco, eliminate the illegal market, protect against exposure to secondhand smoke in public places, fully prohibit any form of advertising, sponsorship and promotion of cigarettes and related products, enforcing warnings on cigarette packets, and make it impossible to sell to minors. The governmental sphere should also include socioeconomic actions such as avoiding the wide capillarity of 
sales outlets (which makes it difficult to supervise and restrict sales to minors), and encourage the substitution and diversification of tobacco cultivation, replacing it with food crops. These socioeconomic actions are aimed at reducing the prevalence of smoking, onset of smoking behaviors, and the costs of treating tobacco-related diseases (higher costs of medical care, longer bed retention during illness and need for more frequent assistance, higher number of early deaths, more disability in the higher productivity age group, more frequent increase of pension requests, higher absenteeism at work, greater number of accidents, income deviation with less spending on basic necessities to attend to cigarette consumption). These actions also combat the losses generated by the tobacco production chain, such as the strenuous work of cultivating and curing tobacco, the contamination of the worker by pesticides, the indebtedness of the farmers, a high rate of suicide and a higher rate of child labor in tobacco farming, with health problems such as green tobacco sickness.

The ecological actions aim to combat the losses in the tobacco production chain, caused to the environment, tobacco cultivation (soil depletion, reduction of N, P, K contents and its contamination by the intense use of fertilizers and pesticides), tobacco curing (burning of forest for heat production) and marketing of cigarettes (preparation of cellulose from cigarette paper requires the clearing of a tree for the production of 300 cigarettes), as well as fires in the woods and houses due to the inadequate disposal of lit cigarettes (30\%).

Legislative actions must be supported at the federal, state and municipal levels, with a preventive priority view. ${ }^{2,3}$

In addition to decrees, ordinances, resolutions, measures and normative instructions, federal laws are the most important and prioritary acts, since compliance with them is mandatory throughout the country and subject to inspection by the public authorities.

The interference of major tobacco lobbyists in both houses of the National Congress should not be overlooked as they work to prevent, delay, weaken and hamper the adoption of effective legislation to control smoking, as well as to implement measures ${ }^{4}$ mediated by the executive power, such as hindering the advancement of tobacco control in Brazil and the world. There is clear evidence that these industries have historically acted to deny the scientific evidence of the harm caused by cigarettes and confuse pubic opinion, governments, and consumers. This fact was well recognized and documented in the US legal history in a 2006 sentence pronounced by Judge Gladys Kessler after the US federal government filed a lawsuit in 1999 against nine tobacco companies (among them Phillip Morris and British American Tobacco, the parent company of Brazil's Souza Cruz) for violating legislation that deals with organized crime, extortion and corrupt organizations. In this landmark ruling, the judge acknowledged that the industry is behind the tobacco epidemic and that the companies acted together and in a coordinated way to deceive public opinion, the government, the health community and consumers. The decision dissects overwhelmingly and staggeringly the evidence of unethical strategies and lack of commitment to the life and health of smokers and nonsmokers for the benefit of the industry by lying, cheating, neglecting, and fraudulently conspiring against the States United and the world. The importance of this decision is the impact on the notable ignorance of the judiciary branch, other legal operators, consumers, the government and civil society about the strategies of the tobacco industry in the world and also in Brazil. ${ }^{5}$

Due to the historical performance of the tobacco industry, which is deleterious to public health, there is a fundamental and irreconcilable conflict between the interests of these industries and public health.

In Brazil, the first bill was presented to the House of Representatives in 1965 by congressman Ivan Lins (Bill No. 2602/1965), instituting an obligation to warn about the harmful effects of tobacco smoke on the packaging of cigarette packs. In the Senate, the year was 1971. The bill presented by senator José Lindoso (Bill 57/1971) established a partial prohibition of tobacco advertising on $\mathrm{TV}$ and Radio, and its commercial regulation, reiterating mandatory warning on cigarette packs and non-permission to sell to minors. In the same year, the Brazilian Federal Medical Board (CFM), with its Resolution No. 440 , dated $6 / 11 / 71$, began not to allow smoking during meetings of the Board, Plenary and Commissions..$^{6-8} \mathrm{CFM}$ Alert No. 001/2014 draws attention to the consumption of hookah pipes and electronic cigarettes (e-cigarettes).

Prior to this period, the first Federal Law on the subject was approved in 1940 (Federal Law 2848/1940), in which a mention is made regarding smoking of "periclitation of life and health" in article 132, and "exposing life or health to direct or imminent danger"(Penal Code), by exposing life or health to the harmful effects of tobacco. In the Consolidation of Labor Laws/Workplace Safety and Health ACT, Decree Law No. 5482/1943 determines, among the duties, that shipping workers must not smoke, use alcohol or carry firearms in the workplace.

It should be emphasized that Federal Health Law (Federal Law No. 6437/1977), the Consolidation of Labor Laws/ Workplace Safety and Health ACT (Federal Law 6514/19770), 
the Brazilian Constitution of 1988, the Statute of the Child and Adolescent (Federal Law No. 8069/1990 with several amendments), the Consumer Protection Code (Federal Law No. 8078/1990 with several amendments), the Law on Crimes Against the Taxation and Economic System and Consumer Relations (Federal Law No. 8137/1990), the National Traffic Code (Federal Law No. 9503/1997), the Environmental Crimes ACT (Federal Law No. 9605/1998 with various amendments), the National Health Surveillance System Law/ANVISA No. 9782/1999, RDC No. $14 / 2012$, the prohibition of additives - suspended by injunction of the Supreme Court) and the Reintegra Law (provides for increase of IPI tax on cigarettes - Federal Law 12546/2011 - Executive, unregulated) all have mechanisms to restrict tobacco use. GM/MS Directive No. 655 of 09/10/1985 created the Advisory Group of the Ministry of Health for Tobacco Control in Brazil.

In addition to the above, Federal Law No. 7488/1986 (establishing the National Day Against Tobacco - celebrated on August 29 of each year) and Federal Law No. 9294/1996 (restriction on the use and products) were approved. The latter regulates Article 220, paragraph 4, of the Brazilian Constitution, which provides that commercial tobacco advertising shall be subject to legal restrictions and shall contain warnings about the harm arising from its use.

Law 9294/1996 has been amended over the years through other laws, the most recent amendment being added by Law 12546/2011, and regulated by Decree $8262 / 2014$, which now prohibits smoking in closed public places, without the permission of the so-called smoking points in closed public places, and introduced restrictions on the commercial advertising of tobacco products displayed at points of sale.

It should be noted that, in 2005, Brazil ratified the Framework Convention on Tobacco Control (FCTC-WHO) through Decree 5658/2006, after approval by Laws $44 / 2003$ and $1281 / 2004$. From this, the norm integrates the Brazilian legal system and the country has the obligation to implement the tobacco control measures provided there, as a state program and not as an option for a government program. To date, 180 countries have acknowledged the treaty.

The FTCT-WHO is the reference standard for tobacco control measures, as it is the result of scientific evidence and best practices for the adoption of effective policies aimed at reducing smoking and protecting all people from passive smoking. It was negotiated under the auspices of the World Health Organization, Brazil was one of the first countries to sign it, and constitutes the first international public health treaty. ${ }^{9-11}$

\section{Овjective}

Presentation and analysis of the survey of bills presented in both federal legislative houses (House of Representatives and Senate) and the laws resulting from these activities.

\section{Method}

The legislative activities of the National Congress can be illustrated by the survey of bills submitted in the period from 1965 to 2015 in the House of Representatives, totaling 254, and in the Senate, from 1971 to 2015, totaling 68, focusing on the most diverse aspects of the control of smoking.

\section{Results}

Out of this total number of bills submitted, the following results are presented in Table 1 and Table 2.

\begin{tabular}{|c|c|c|c|c|}
\hline \multirow[t]{2}{*}{ Result } & \multicolumn{2}{|c|}{$\begin{array}{l}\text { House of } \\
\text { Representatives }\end{array}$} & \multicolumn{2}{|c|}{ Senate } \\
\hline & $\mathbf{N}$ & $\%$ & $\mathbf{N}$ & $\%$ \\
\hline Shelved/Rejected/Returned & 175 & 68.9 & 13 & 19.1 \\
\hline No results & 38 & 14.9 & 23 & 33.8 \\
\hline \multicolumn{4}{|l|}{ Commissions } & 4.4 \\
\hline Amendments/Law Annexes & 5 & 2.0 & 29 & 42.7 \\
\hline \multicolumn{4}{|l|}{ Norms/Proposition of Origin } & - \\
\hline Transformed into Law & 2 & 0.8 & - & - \\
\hline Total & 254 & 100.0 & 68 & 100.0 \\
\hline
\end{tabular}

TABLE 2 Results of the activities of non-governmental organizations $(A M B / A C T)$ and the federal government (MS/INCA).

\begin{tabular}{llllll} 
Period & $\begin{array}{l}\text { Activities of } \\
\text { the Entities }\end{array}$ & \multicolumn{2}{l}{$\begin{array}{l}\text { House of } \\
\text { Representatives }\end{array}$} \\
\cline { 3 - 6 } & & $\mathbf{N}$ & $\%$ & $\mathbf{N}$ & $\%$ \\
\hline $1979-1984$ & AMB & 51 & 20.2 & 3 & 4.8 \\
\hline $1985-2007$ & MS/INCA & 143 & 56.8 & 32 & 50.8 \\
\hline $2008-2015$ & ACT & 58 & 23.0 & 28 & 44.4 \\
\hline Total & & 252 & 100.0 & 63 & 100.0 \\
\hline
\end{tabular}

\section{Discussion AND Conclusion}

It is noteworthy that of this total movement of the National Congress, in addition to the approval and ratification of the FCTC-WHO, there were only two approved laws essentially aimed at smoking: Federal Law No. 7488 of June 11, 1986, which establishes the National Day 
Against Tobacco (celebrated on August 29 of each year), and Federal Law No. 9294 of September 15, 1996, which regulates restrictions on the use and advertising of tobacco products, beverages alcoholic beverages, drugs, therapies and agricultural pesticides, pursuant to paragraph 4 of article 220 of the Federal Constitution. This law was regulated and amended by Decree Laws 2018/10.01.1996 (establishes definitions of collective and work premises, aircraft and collective transport vehicles, a properly isolated area and exclusively destined for this purpose, advertising and packaging of tobacco products, in addition to infractions and penalties) and 3157/8.27.1999 (in the case of aircraft and collective vehicles, smoking will only be allowed once an hour has elapsed). Other changes were made by Provisional Measure No. 18142/2.26.1999 (the advertisement will have warnings, both spoken and written, whenever possible), Ordinance No. 695/6.1.1999 (disclosure of the contents of warnings on the harms caused by the consumption of tobacco), and Federal Laws No. 10167/12.27.2000 (prohibition of the use of tobacco products in aircraft and other public transport vehicles) and 10702/2.14.2003 (prohibition to sell in public administration bodies or entities), Provisional Measure No. 118/4.3.2003 (prohibition of sponsorship of international sporting events by cigarette brands), Resolution RDC 54/2008 - Anvisa (regulation of new images and warning phrases in tobacco products), Federal Law No. 12546/2011 (determining the increase of prices and taxes, end of smoking areas in closed places, as well as total prohibition of advertising), Decree Law No. 8262/5.31.2014 (changes to the definitions of enclosed collective premises, point of sale, packaging of tobacco product, derivative or non-derivative of tobacco, exclusions of prohibition of smoking in places and special situations), Interministerial Ordinance/MTE/MS No. 2647/12.4.2014 (regulation of insulation, air ventilation and exhaustion, and measures to protect workers from exposure to tobacco smoke indoors) and Resolution Anvisa DC/No. 14/4.13.2015 (standards for placing sanitary warnings on the packaging of tobacco products).

Another aspect that should be highlighted is the relation between periods in which bills were presented at the House of Representatives and stricter action by non-governmental organizations and the federal government. In the House of Representatives, in the period 1979-1984, when 51 projects were presented, there was intense mobilization of the Brazilian Medical Association (AMB); in the period 1985-2007, there were 143 projects presented by the Ministry of Health/National Institute of Cancer José Alencar Gomes da Silva (MS/INCA); and in the period 2008-
2015, 58 projects were filed by the Alliance for Tobacco Control Health Promotion (ACT). In the Senate, in the first period, three projects were presented; in the second period, 32 projects; and in the third period, 28 projects.

Despite the intense "lobbying" of the tobacco industry during all these periods, Brazil has a tobacco control legislation that is constantly updated, which has contributed to the reduction of the prevalence of smoking in the country in the past 10 years. This is only possible through the joint action of the MS/INCA and non-governmental organizations such as the AMB and the ACT in order to guarantee the commitment of parliamentarians from both Legislative Houses, as evidenced by data from the Vigitel project of the Ministry of Health. ${ }^{12}$

\section{ACKNOWLEDGEMENT}

We thank Napoleão Salles, consultant in Brasília of the AMB, for compiling the bills presented in the Senate and the House of Representatives.

\section{Resumo}

Importância das medidas legislativas no controle do tabagismo no Brasil

Introdução: No programa de controle do tabagismo, devem ser planejadas ações educativas, socioeconômicas, ecológicas e legislativas. As ações legislativas devem ser nos âmbitos federal, estadual e municipal, com visão prioritária preventiva, sendo as federais os atos mais importantes e prioritários.

Objetivo: Levantamento dos projetos de lei apresentados em ambas as casas legislativas em âmbito federal, Câmara dos Deputados e Senado e das leis resultantes.

Métodos: Na Câmara dos Deputados, foram apresentados 254 projetos de lei, no período de 1965 a 2015, enquanto no Senado, 68, entre 1971 e 2015.

Resultados: $\mathrm{Na}$ Câmara dos Deputados, dos 254 projetos de lei, $68,9 \%$ foram arquivados/rejeitados/devolvidos, $14,9 \%$ não possuem resultado, $12,2 \%$ estão em tramitação/ comissões, $2,0 \%$ se referem a alterações/anexos de lei, 1,2\% foram transformados em norma jurídica/proposição de origem e $0,8 \%$ foram transformados em leis. No Senado, dos 68 projetos de lei, 19,1\% foram arquivados, $33,8 \%$ não possuem resultado, 4,4\% estão em tramitação e $42,7 \%$ se referem a alterações de lei. A atuação se mostrou mais ativa nos períodos de 1979-1984 pela Associação Médica Brasileira (AMB), 1985-2007 pelo Ministério da Saúde/ Instituto Nacional de Câncer (MS/INCA) e 2008-2015 pela Aliança de Controle do Tabagismo (ACT). 
Conclusão: A legislação de controle do tabagismo tem permanentemente avançado, contribuindo aos parlamentares de ambas as Casas Legislativas, por parte do MS/ Inca e da sociedade civil comprometida com o controle do tabagismo, como as organizações não governamentais (AMB e ACT).

Palavras-chave: tabagismo/prevenção \& controle, hábito de fumar/legislação \& jurisprudência, legislação.

\section{References}

1. Associação Médica Brasileira, Conselho Federal de Medicina, Agência Nacional de Saúde Suplementar. Tabagismo. In: Primeiras Diretrizes Clínicas na Saúde Suplementar. Rio de Janeiro: ANS; 2005. p. 254-73.

2. Rosemberg J. Aspectos educativos, legais, econômicos e sociais do tabagismo, Direitos dos não fumantes. Arq Bras Tuberculose Doenças Tórax. 1979; 38:31-46.

3. Bechara MJ, Jacobs OL. Legislação e combate ao tabagismo. In: Fumo ou saúde. São Paulo: Bradepca; 1985. p. 299-312.
4. Correia PCRP, Houat MFA. Quais as principais razões, ações de Advocacy no controle do tabagismo? In: Araújo AJ, editor. Manual de condutas e práticas em tabagismo. São Paulo: A.C. Farmacêutica; 2012. p. 424-6.

5. Aliança de Controle do Tabagismo. O veredicto final: trechos do processo Estados Unidos x Philip Morris. Available from: http://www.actbr.org.br/ uploads/conteudo/176_sentencaKesslertraducao.pdf

6. Médicos e parlamentares resolvem combater o fumo. O Médico Moderno. $1965 ; 22-34$.

7. Mirra AP, Rosemberg J. A história da luta contra o tabagismo no Brasil: trinta anos de ação. 2. ed. Salvador: Sociedade Brasileira de Cancerologia; 2005.

8. Mirra AP, Rosemberg J, Araújo AJ. Marcos históricos do controle do tabaco no Brasil. In: Araújo AJ, editor. Manual de condutas e práticas em tabagismo. São Paulo: A.C. Farmacêutica; 2012. p. 6-12.

9. World Health Organization. Framework Convention on Tobacco Control. Update reprint 2004. Geneva: WHO; 2003.

10. Sociedade Brasileira de Pneumologia e Tisiologia. O que representa o Tratado Mundial para o Controle do Tabaco. In: Araújo AJ, editor. Manual de condutas e práticas em tabagismo. São Paulo: A.C. Farmacêutica; 2012. p. 63.

11. Associação Médica Brasileira, Ministério da Saúde/Instituto Nacional de Câncer José Alencar Gomes da Silva, Aliança de Controle do Tabagismo. Evidências científicas sobre tabagismo para subsídio ao Poder Judiciário. São Paulo: Associação Médica Brasileira; 2013. p. 50

12. Brasil, Ministério da Saúde. Vigitel, Brasil, 2014: Vigilância para doenças crônicas por inquérito telefônico. Brasília: INCA; 2015. 